\title{
Factors Affecting Accidents Risks among Truck Drivers In Egypt
}

\author{
Ahmed Fathalla Elshamly ${ }^{1}$, Ragaa Abd El-Hakim ${ }^{2}$, and Hafez Abbas Afify ${ }^{3}$ \\ ${ }^{1}$ Tanta University, Egypt \\ ${ }^{2}$ Public Works Engineering Department, Faculty of Engineering, Tanta, Egypt \\ ${ }^{3}$ Public Works Engineering Department, Faculty of Engineering, Tanta, Egypt
}

\begin{abstract}
Egypt is ranked among the countries with the highest rates of road accidents. According to the American Chamber of Commerce more than $96 \%$ of Egypt's goods are transported by trucks and due to their large volume and excessive weight, the severity and number of truck accident fatalities are much higher than other vehicles in Egypt. The present study aims at identifying truck driver's behavior and its influence on crash involvement. Due to the shortage in recording accident data and the inaccurate road accident audit, data was collected from several governorates in Egypt through questionnaire. Questionnaire forms were filled out through personal interviews with truck drivers. The total number of respondents was 643 . The final analysis was made on the 615 questionnaires with complete answers. The data was analyzed and logistic regression was applied to accident related data to examine the contributing factors affecting accident occurrence of truck drivers. Results showed that fatigue in terms of driving hours (continuous and total) and lack of sleep, drug use during driving, and driver obesity are the most influencing factors on the occurrence of truck accidents in Egypt. The findings of this research highlight the important role human factors have on the risk of crash involvement amongst Egypt's truck drivers and the need to improve their work conditions.
\end{abstract}

\section{Introduction}

Road safety is a very serious issue in Egypt and the Middle East in general. The crash numbers and road fatalities in Egypt are very high. The victims of road fatalities are mostly young and middle aged people which has a great impact on the emerging economy in Egypt. Therefore, the reduction or prevention of traffic accidents is one of the top priorities of researchers, community and the government in Egypt [1] .Truck accidents, in particular, are one of the most important issues facing Egypt's road safety at present due to the large number of fatalities and death toll [2]. A key aspect of trucks is their large size and weight which represents a great danger to other vehicles and their passengers, and results in the complexity of any accident involving trucks. The aforementioned feature of trucks requires that truck drivers and other drivers as well be cautious about the risk represented by large vehicles. Behavior is a fundamental part of people which affects their perception, attitudes and driving character. This behavior concerned characteristics have a direct impact on one's safety or vulnerability to traffic accidents. Central to the entire results of truck accidents is the tragic loss of other drivers' lives, pedestrians, and the truck drivers themselves. Behavior of truck drivers' effect on the ratio of truck accidents is the main concern of many researchers. Truck accidents have many reasons, in some cases, lack of attention, including general inattention, misdirected attention, falling asleep, and distraction [3].One of the most common sleep disorders is excessive daytime sleepiness (EDS) which affects about 4 to $12 \%$ of the population, and causes psychological stress and lack of productivity at work plus an increase in the risk of accidents [4]. Sleeping habits could be a major contributor to truck accidents due to lack of sleep, long shifts, continuous driving hours, long journeys and tight timetables that lead to fatigue of drivers [1]. Obesity is also a risk factor for automotive accidents. Obese truck drivers have a significantly higher risk of causing accidents than non obese truck drivers [5]. The National Transportation Safety Board concluded that more than $30 \%$ of fatal-to-the-driver truck crashes are fatigue related [6]. Overweight imposes abnormal body movements, which can lead to the limited range of movement of major joints, decreased muscle strength and the inability to maintain fixed positions for long periods, and reduces visual observation [7]. Unfortunately, some truckers use illegal materials such as alcohol, cannabis and cocaine [8]. Traditionally, many researchers have subscribed to the belief that drivers take drugs on widely varying estimates. This is known by self reporting questionnaires or through a drug test but most reported was largely the use of anabolic substances [8]. Aggressive driving represents a serious problem in today's society with an increasing number of drivers identifying this issue as alarming[15]. Degrees of aggressive driving behaviors caused by violations of 
traffic rules result in hazards for other road users [16] Many accidents are caused by errors and violations resulting from Aggressive driving [17].

\section{Objectives}

The main purpose of the current study is to identify the factors contributing to accidents among truck drivers in Egypt. It also aims at recommending the necessary solutions for the treatment of these factors.

\section{Data collection and study area}

Due to the lack of accurate accident data, a Driver Behavior Questionnaire (DBQ) was formulated to collect important information needed to assess and evaluate the relationship between truck drivers' behavior and traffic accident occurrence. Based on the studied literature and keeping in mind the Egyptian habits, 47 different questions were included in the DBQ and arranged in five different sections. The covered sections are demographic characteristics, accident exposure, distraction while driving, aggressive driving, and different driver behavior aspects. The aggressive driving part of the questionnaire inquired about speeding, racing with others, driving on the form of sutures, overconfidence that makes the drivers violate traffic laws, drug use traffic offense, and drug use in general. A total of 643 truck drivers were interviewed, 28 of whom were excluded because the drivers refused to complete the questionnaire. All of the interviewed drivers were male drivers (it is not common for females to work in this profession in Egypt). Questionnaire interviews regarded the place of residence of all drivers in order to cover all different parts of Delta region and cover all the international highways inside Egypt. Questionnaire forms were compiled in three governorates, namely; Kafr El-Sheikh, Gharbia, and Dakahlia. The survey was conducted between April and July 2015.

\section{Analysis and discussion}

The analysis of the remaining 615 respondents was done using the statistical package for social sciences (SPSS) program. The results of the most important questions of the questionnaire are summarized in table 1.

Table 1. Percentage of drivers by study variables

\begin{tabular}{|c|c|c|c|c|}
\hline \multicolumn{5}{|c|}{ Demographic Characteristics } \\
\hline \multirow{2}{*}{$\begin{array}{l}\text { Age } \\
\text { (year) }\end{array}$} & $21-29$ & $30-39$ & $40-50$ & \\
\hline & $22.8 \%$ & $31.8 \%$ & $33 \%$ & $12.5 \%$ \\
\hline \multirow{2}{*}{$\begin{array}{c}\text { Weight } \\
(\mathrm{kg})\end{array}$} & $<70$ & $70-89$ & $90-110$ & $>110$ \\
\hline & $7.6 \%$ & $48.6 \%$ & $37.4 \%$ & $6.3 \%$ \\
\hline \multirow{2}{*}{$\begin{array}{l}\text { Height } \\
(\mathrm{cm})\end{array}$} & $<160$ & $160-175$ & $176-190$ & $>190$ \\
\hline & $7.3 \%$ & $48.8 \%$ & $40.3 \%$ & $3.6 \%$ \\
\hline \multirow{2}{*}{ BMI } & Normal & \multicolumn{2}{|c|}{ Over weight } & Obese \\
\hline & $51.1 \%$ & \multicolumn{2}{|c|}{$27.3 \%$} & $21.6 \%$ \\
\hline Monthly & $<1000$ & $1000-25$ & $2500-$ & $>4000$ \\
\hline
\end{tabular}

\begin{tabular}{|c|c|c|c|c|}
\hline \multirow{2}{*}{$\begin{array}{l}\text { income } \\
\text { (Pound) }\end{array}$} & & \multicolumn{3}{|c|}{4000} \\
\hline & $11.4 \%$ & $37.9 \%$ & $35.9 \%$ & $14.8 \%$ \\
\hline \multirow{2}{*}{$\begin{array}{l}\text { Driving } \\
\text { Experienc } \\
\mathrm{e}(\text { Year) }\end{array}$} & $<5$ & $5-9$ & $\begin{array}{c}10- \\
15\end{array}$ & $>15$ \\
\hline & $18.4 \%$ & $39.7 \%$ & $33.8 \%$ & $8.1 \%$ \\
\hline \multirow{2}{*}{$\begin{array}{l}\text { Education } \\
\text { al Level }\end{array}$} & Primary & Preparatory & $\begin{array}{c}\text { Secon } \\
\text { dary }\end{array}$ & $\begin{array}{c}\text { Universi } \\
\text { ty }\end{array}$ \\
\hline & $9.9 \%$ & $31.4 \%$ & $45.4 \%$ & $13.3 \%$ \\
\hline \multirow{2}{*}{$\begin{array}{c}\text { Total } \\
\text { Driving } \\
\text { Hours }\end{array}$} & $1-5$ & $6-10$ & $\begin{array}{c}11- \\
15\end{array}$ & $>15$ \\
\hline & $12.5 \%$ & $35.5 \%$ & $35.6 \%$ & $16.6 \%$ \\
\hline \multirow{2}{*}{$\begin{array}{c}\text { Continuo } \\
\text { us } \\
\text { Driving } \\
\text { Hours }\end{array}$} & $<4$ & $4-6$ & $7-8$ & $>8$ \\
\hline & $16.7 \%$ & $40.7 \%$ & $24.1 \%$ & $18.5 \%$ \\
\hline \multirow{2}{*}{$\begin{array}{c}\text { Sleeping } \\
\text { Hours } \\
\end{array}$} & $<6$ & \multicolumn{2}{|l|}{$7-8$} & $<8$ \\
\hline & $69.6 \%$ & \multicolumn{2}{|c|}{$27.2 \%$} & $3.3 \%$ \\
\hline \multirow{7}{*}{$\begin{array}{c}\text { Distractio } \\
\mathrm{n} \\
\text { Activities }\end{array}$} & $\begin{array}{c}\begin{array}{c}\text { Variabl } \\
\text { e }\end{array} \\
\end{array}$ & Not at All & $\begin{array}{c}\text { Somet } \\
\text { imes }\end{array}$ & Often \\
\hline & $\begin{array}{c}\text { Eat } \\
\text { while } \\
\text { driving }\end{array}$ & $32.5 \%$ & $44.2 \%$ & $23.3 \%$ \\
\hline & $\begin{array}{c}\text { Smokin } \\
\mathrm{g}\end{array}$ & $16.1 \%$ & $47 \%$ & $36.9 \%$ \\
\hline & $\begin{array}{c}\text { Cell } \\
\text { phone }\end{array}$ & $15.9 \%$ & $55.3 \%$ & $28.8 \%$ \\
\hline & Radio & $23.6 \%$ & $46 \%$ & $30.4 \%$ \\
\hline & DVD & $45.9 \%$ & $33.2 \%$ & $21 \%$ \\
\hline & Talking & $21.3 \%$ & $37.2 \%$ & $41.5 \%$ \\
\hline \multirow{5}{*}{$\begin{array}{l}\text { Aggressiv } \\
\text { e Driving }\end{array}$} & Sutures & $56.9 \%$ & $31.1 \%$ & $12 \%$ \\
\hline & Racing & $44.2 \%$ & $44.6 \%$ & $11.2 \%$ \\
\hline & $\begin{array}{c}\text { Speedin } \\
\mathrm{g}\end{array}$ & $40.5 \%$ & $42.9 \%$ & $16.4 \%$ \\
\hline & $\begin{array}{c}\text { Self } \\
\text { Overcon } \\
\text { fidence }\end{array}$ & $54.5 \%$ & $36.4 \%$ & $9.1 \%$ \\
\hline & $\begin{array}{c}\text { Drug } \\
\text { use } \\
\text { Traffic } \\
\text { Offense }\end{array}$ & $56.3 \%$ & $34.1 \%$ & $9.6 \%$ \\
\hline $\begin{array}{c}\text { Self } \\
\text { Reported } \\
\text { Drug Use }\end{array}$ & $\begin{array}{c}\begin{array}{c}\text { Before } \\
\text { long } \\
\text { Journey } \\
\text { s }\end{array} \\
20.5 \% \\
\end{array}$ & $37.4 \%$ & $27.6 \%$ & $14.5 \%$ \\
\hline \multirow{2}{*}{$\begin{array}{l}\text { Driver } \\
\text { Behavior }\end{array}$} & $\begin{array}{c}\text { Sleep } \\
\text { while } \\
\text { Driving }\end{array}$ & $37.2 \%$ & $49.6 \%$ & $13.2 \%$ \\
\hline & $\begin{array}{l}\text { Lack of } \\
\text { Sleep }\end{array}$ & $30.1 \%$ & $52 \%$ & $17.9 \%$ \\
\hline $\begin{array}{l}\text { Number } \\
\text { of } \\
\text { Accidents }\end{array}$ & $1-2$ & $2-3$ & $4-5$ & $<5$ \\
\hline $\begin{array}{c}\text { Total } \\
\text { Driving } \\
\text { Hours }\end{array}$ & $52 \%$ & $38 \%$ & $7 \%$ & $3 \%$ \\
\hline $\begin{array}{l}\text { Fatalities } \\
\text { Number }\end{array}$ & 1 & 2 & 3 & $<3$ \\
\hline $\begin{array}{l}\text { Continuo } \\
\text { us } \\
\text { Driving } \\
\text { Hours }\end{array}$ & $51 \%$ & $32 \%$ & $13 \%$ & $5 \%$ \\
\hline
\end{tabular}


Strong evidence of aggressive driving behavior was found. $12 \%$ of drivers often drive on the form of sutures, $44.6 \%$ of drivers sometimes race with other cars, $16.4 \%$ of drivers exceed the speed limit on the roads and $9.1 \%$ of drivers often have overconfidence due to size of the truck, this represents a significant danger to other cars.
From the literature, it was known that there is a strong relationship between driver fatigue, obesity and crash involvement. To assess the effect of fatigue on accident exposure, variety of questions were asked in the questionnaire. These questions inquired about the number of sleeping hours, and continuous and total driving hours.
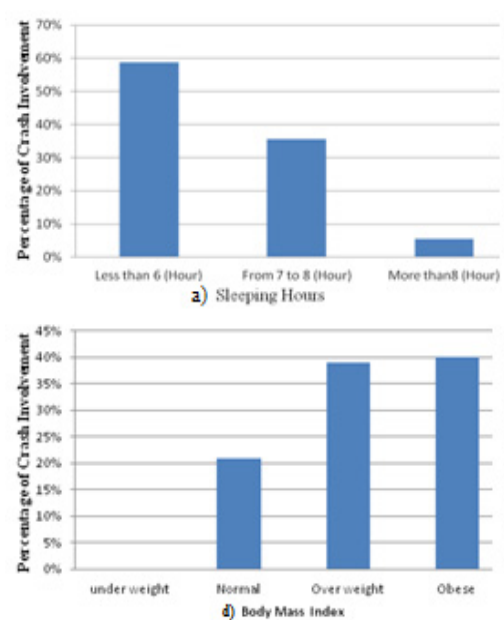

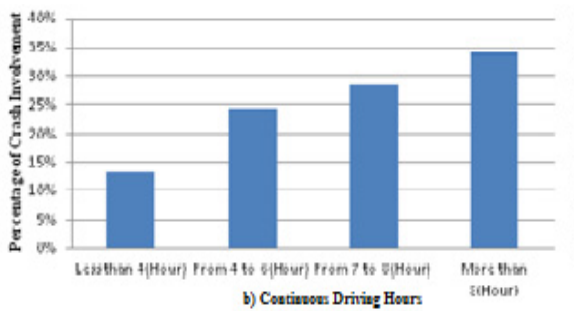
b) Contivoves Driving Hour

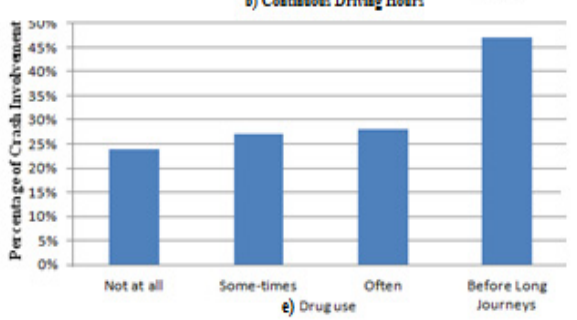

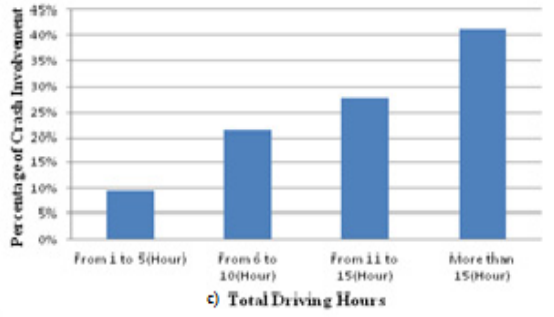

a) Sleeping Hours

b) Continuous Driving Hours

c) Total Driving Hours

d) Body Mass Index

e) Drug Use

Figure 1. Percentage of Drivers Involved in Accidents by a- Sleeping Hours, b- Continuous Driving Hours, c- Total Driving Hours, dBody Mass Index, e- Drug Use.

Figure 1,a shows that the less the truck driver sleeps the more exposure to traffic accident. This finding is in agreement with Souza findings [4]. figure 1,b illustrates that percentage of crash involvement increases when the number of continuous driving hours per day increases. figure $1, \mathrm{c}$ presents the relationship between percentage of crash involvement and the number of total driving hours per day. It is apparent from this figure that the number of total driving hours per day is proportional to crash involvement. Unfortunately, in Egypt, there are no regulations that limit the number of continuous driving hours or the total driving hours per day for truckers. In fact, the current traffic laws encourage and forces truckers to drive long periods as every 24 hours they are charged for the goods they transport. In order to understand how driver obesity is related to crash involvement, the drivers were asked about their weight and height, and the body mass index (BMI) was calculated. The drivers were classified according to BMI as underweight, normal, over weight and obese[9]. Figure $1, \mathrm{~d}$ shows that obese and overweight truck drivers are the most involved in traffic accidents by $40 \%$ obese, $39 \%$ over weight, $21 \%$ normal drivers. Percentage of truck accidents was associated with higher rates of obesity. Percentage of obese and overweight drivers are so close that indicates most of truck drivers in a risk category, Surveys such as that conducted by James et al [6] showed that obese drivers represent more than $50 \%$ of commercial truck drivers. To measure the effect of drug use on crash involvement, a question inquiring about how frequent the driver uses drugs was asked and the answers were associated with crash involvement. From figure 1,e it is apparent that truck drivers who take drugs before long journeys are the most involved in accidents by $47 \%$. Unfortunately, this result confirms that many truck drivers are using drugs before long journeys. Their belief is that this helps them to focus and continue to drive long distances. Table 2 illustrates the effect of long driving hours (continuous and total) on people who sleep less. From the table, it can be seen that drivers who sleep less than 6 hours, and drive more than 8 hours continuously are the most exposed to accident occurrence (31\%). The table also shows that drivers who sleep less than 6 hours, and drive more than 15 hours a day are more involved in crash accidents $(42 \%)$. It can be seen that percentage of accidents to drivers who sleep less than 6 hours decreased whenever total driving hours were less. This explains the significant impact of fatigue due to long driving hours on the occurrence of accidents.

Table 2. Percentage of Accident occurrence to Drivers who sleep less than 6 hours by total and continuous driving hours

\begin{tabular}{|c|c|c|c|c|}
\hline \multicolumn{5}{|c|}{ Drivers sleep Less than 6 (Hour) } \\
\hline $\begin{array}{c}\text { Continuous } \\
\text { driving } \\
\text { hours }\end{array}$ & $\begin{array}{c}\text { Less than } \\
4 \text { (Hour) }\end{array}$ & $\begin{array}{c}\text { From } 4 \text { to } \\
6 \text { (Hour) }\end{array}$ & $\begin{array}{c}\text { From } 7 \text { to } \\
8 \text { (Hour) }\end{array}$ & $\begin{array}{c}\text { More } \\
\text { than } \\
8 \text { (Hour) }\end{array}$ \\
\cline { 2 - 5 } & $14 \%$ & $30 \%$ & $25 \%$ & $31 \%$ \\
\hline $\begin{array}{c}\text { Total } \\
\text { driving } \\
\text { hours }\end{array}$ & $\begin{array}{c}\text { From } 1 \text { to } \\
5 \text { (Hour) }\end{array}$ & $\begin{array}{c}\text { From } 6 \text { to } \\
10(\text { Hour) }\end{array}$ & $\begin{array}{c}\text { From } 11 \text { to } \\
15(\text { Hour) }\end{array}$ & $\begin{array}{c}\text { More } \\
\text { than } \\
15 \text { (Hour) }\end{array}$ \\
\cline { 2 - 5 } & $11 \%$ & $19 \%$ & $28 \%$ & $42 \%$ \\
\hline
\end{tabular}

Table 3 summarizes the percentage of drivers for different accident related variables (sleeping hours, continuous driving, total driving hours, body mass index and drug use). It can be seen from this table that $59 \%$ of drivers involved in accidents sleep less than 6 hours. $79 \%$ of drivers who are exposed to accidents are $40 \%$ overweight and obese. Also it can be noted that $28 \%$ of drivers involved in accident often take drugs and $47 \%$ do that before long journeys. 
Table 3. Percentage of Drivers involved in accidents related Variables( NA= Not Applicable )

\begin{tabular}{|c|c|c|c|c|}
\hline \multirow{2}{*}{$\begin{array}{l}\text { Sleeping } \\
\text { Hours }\end{array}$} & $\begin{array}{c}\text { Less } \\
\text { Than } 6\end{array}$ & 7-8 Hours & \multicolumn{2}{|c|}{ More Than 8 Hours } \\
\hline & $59 \%$ & $36 \%$ & \multicolumn{2}{|c|}{$5 \%$} \\
\hline \multirow[t]{2}{*}{$\begin{array}{c}\text { Continuous } \\
\text { Driving }\end{array}$} & $\begin{array}{c}\text { Less } \\
\text { than } \\
\text { 4(Hour) }\end{array}$ & $\begin{array}{c}\text { From } 4 \text { to } \\
6 \text { (Hour) }\end{array}$ & $\begin{array}{c}\text { From } 7 \\
\text { to } \\
8 \text { (Hour) }\end{array}$ & $\begin{array}{c}\text { More } \\
\text { than } \\
8 \text { (Hour) }\end{array}$ \\
\hline & $13 \%$ & $24 \%$ & $29 \%$ & $34 \%$ \\
\hline \multirow[t]{2}{*}{$\begin{array}{l}\text { Total } \\
\text { Driving } \\
\text { Hours }\end{array}$} & $\begin{array}{l}\text { From } 1 \\
\text { to } \\
5 \text { (Hour) }\end{array}$ & $\begin{array}{l}\text { From } 6 \text { to } \\
10 \text { (Hour) }\end{array}$ & $\begin{array}{c}\text { From } 11 \\
\text { to } \\
15 \text { (Hour) }\end{array}$ & $\begin{array}{c}\text { More } \\
\text { than } \\
15 \text { (Hour) }\end{array}$ \\
\hline & $9 \%$ & $21 \%$ & $28 \%$ & $41 \%$ \\
\hline \multirow{2}{*}{$\begin{array}{c}\text { Body Mass } \\
\text { Index }\end{array}$} & $\begin{array}{c}\text { Under } \\
\text { Weight }\end{array}$ & Normal & $\begin{array}{c}\text { Over } \\
\text { Weight }\end{array}$ & Obese \\
\hline & NA & $21 \%$ & $39 \%$ & $40 \%$ \\
\hline \multirow[t]{2}{*}{ Drug Use } & $\begin{array}{l}\text { Not at } \\
\text { all }\end{array}$ & Sometimes & Often & $\begin{array}{c}\text { Before } \\
\text { Long } \\
\text { Journeys }\end{array}$ \\
\hline & $24 \%$ & $27 \%$ & $28 \%$ & $47 \%$ \\
\hline
\end{tabular}

\section{Severity of accidents}

Accidents are unplanned and sudden events but they cause damage to person or property. In an accident, there can be more than one type of casualty. Thus, the severity of accident was divided into damage only, injuries only, deaths, damage + injuries, damage + deaths, injuries + deaths, damage + injuries + deaths and other losses are illustrated in Figure 2. It can be seen from this figure that the most frequent type of truck accident severity is $($ damage $=49 \%),($ injuries $=19 \%),($ deaths $=13 \%)$ and $($ damage + injuries + deaths $=6 \%)$.

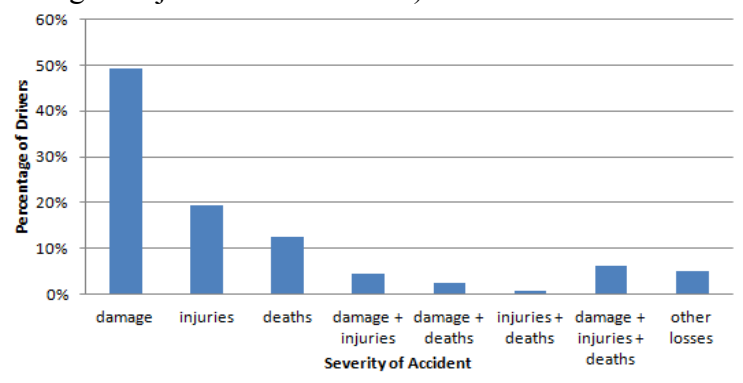

Figure 2. Percentage of Casualties as Reported by Truck Drivers Related to Severity of Accidents

Truck drivers who had an accident or more were asked about the cause of the accident. Figure 3 shows self reported accident causes, namely speeding 19\%, lack of attention $15 \%$, bad weather $13 \%$, drug use $12 \%$, sleepiness $11 \%$ and overloading $6 \%$. Drivers admitted several reasons of accidents by their confessions and compared with the data analysis, that explained that sleep, drug use and obesity are common causes of truck accidents. Fatigue, long driving hours and lack of sleep caused a lack of attention and resulted in accident occurrence.

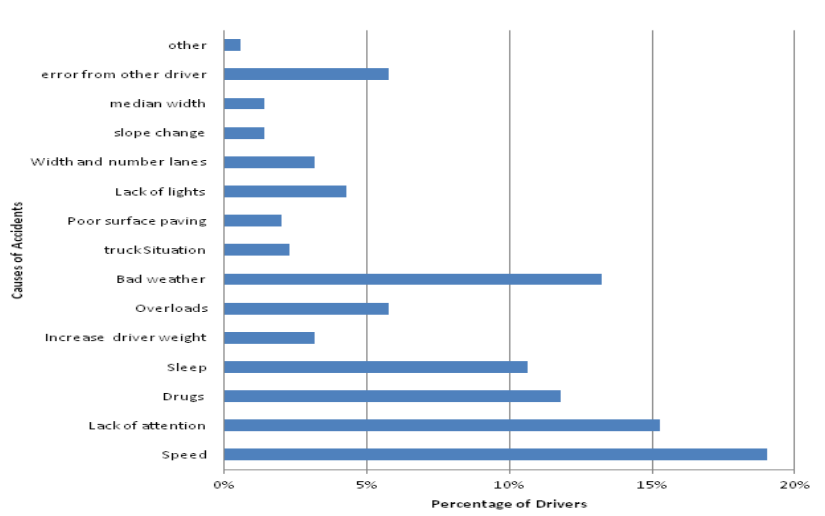

Figure 3. Percentage of Drivers' Self Reported Causes of Accidents

Figure 4 shows that number of death causalities is one killed person in $51 \%$ of fatality accidents, two killed persons in $32 \%$ of fatality accidents, three persons killed in $13 \%$ of fatality accidents and more than three persons in $4 \%$ of fatality accidents as reported by the truck drivers in the questionnaire.

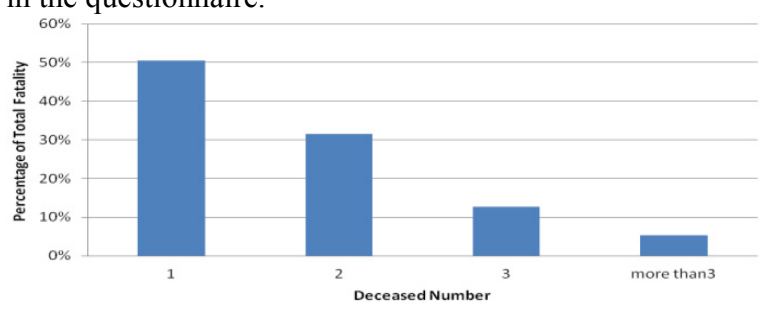

Figure 4. Percentage of Drivers Self Reported Deceased Number at Fatality Accident

\section{Development of driver behaviour models}

The characterization of truck drivers' behavior, statistical analysis and modeling of accident probability were conducted using SPSS. Due to of the nature of the collected data, the binary logistic regression technique was used to develop truck driver behavior models. The method was designed to find factors that were most effective in predicting the probability of accident occurrence. It adds variables to the model in a stepwise base, provided that these variables have significance value less than 0.05 and check for the significance of variables already in the model to consider if any variables should be removed. Several accident probability models were developed considering the influencing factors of fatigue in terms of sleeping hours, continuous and total driving hours, obesity, and drug use. Table 5 contains the two pseudo R2 measures (Cox and Snell \& Nagelkerke) that judge the accuracy of the models. Cox and Snell attempted to calculate the coefficient of determination based on maximum likelihood [12]. It is better to use the Nagelkerke $\mathrm{R}^{2}$, because the Cox and Snell can never quite get to 1 , and is therefore less accurate [13]. In this study drivers slept less than 6 hours, total driving more than 15 hours, continuous driving more than 8 hours, 
obese drivers, and drivers who often use drugs accident models showed $\mathrm{R}^{2}$ values of $0.70,0.64,0.56,0.61$, and 0.6 .

Table 5. $\mathrm{R}^{2}$ Test for model accuracy

\begin{tabular}{|c|c|c|c|}
\hline Accident Model & $\begin{array}{c}-\mathbf{2} \text { Log } \\
\text { likelihood }\end{array}$ & $\begin{array}{c}\text { Cox \& } \\
\text { Snell R }\end{array}$ & $\begin{array}{c}\text { Nagelkerke } \\
\mathbf{R}^{\mathbf{2}}\end{array}$ \\
\hline $\begin{array}{c}\text { Drivers slept less than 6 } \\
\text { hours }\end{array}$ & $206.441 \mathrm{a}$ & 0.47 & 0.70 \\
\hline $\begin{array}{c}\text { Total driving more than 15 } \\
\text { hours }\end{array}$ & $58.765 \mathrm{a}$ & 0.44 & 0.64 \\
\hline $\begin{array}{c}\text { Continuous driving more } \\
\text { than 8 hours }\end{array}$ & $64.113 \mathrm{a}$ & 0.37 & 0.56 \\
\hline Obese drivers & $111.124 \mathrm{a}$ & 0.45 & 0.61 \\
\hline $\begin{array}{c}\text { Use drugs before Long } \\
\text { Journeys }\end{array}$ & $98.609 \mathrm{a}$ & .453 & 0.60 \\
\hline
\end{tabular}

\section{Conclusions and recommendations}

The present paper aimed at investigating the behavior of truck drivers and its impact on crash involvement. Based on the results and analyses of this research the following conclusions were drawn:

- Driver fatigue, driver obesity and drug use emerged as reliable predictors of truck traffic accidents. These results were also confirmed using the odds ratio analysis.

- The casualties of truck accidents were $49 \%$ damage only, $19 \%$ injuries, $13 \%$ deaths and $6 \%$ (damage + injuries + deaths).

- The number of death casualties at fatality accidents were $51 \%$ one person killed, $32 \%$ two persons killed, $13 \%$ three persons killed, $4 \%$ more than three persons killed.

- The developed models demonstrated that the highest influence on probability of accident occurrence is aggressive driving and distraction activities.

- A number of recommendations are suggested to reduce both the incidence and severity of crashes. These include:

- Unless the Egyptian government adopts legal legislation for regular detection of truck drivers' drug usage periodically and apply points system which has different levels of penalties, reduction of accident number and severity will not be attained.

- There is a definite need for updating current traffic laws and regulations especially the penalties for repeated traffic violations.

- Moreover, more real accident data should be made available to researchers for analysis and simulation. This requires establishing electronic database for the accidents including all data.

- Develop a national handbook on the rules and principles of safety driving rules.

- Another important practical implication is that truck drivers should be given extensive and professional training with emphasis on safe driving qualities.

\section{References}

1. Ahmed Mohamed Ismail, H.Y.A., Mohamed Ahmed owais, Analysis and Modeling of Traffic Accidents Causes for Main Rural Roads in Egypt. 2010.

2. World Health Organization. Violence, I.P., and World Health Organization. Global status report on road safety 2013: supporting a decade of action. World Health Organization, 2013.

3. McKnight, A.J., and George T. Bahouth. "Analysis of large truck rollover crashes." Annals of Advances in Automotive Medicine/Annual Scientific Conference. Vol. 52. Association for the Advancement of Automotive Medicine, 2008..

4. Souza, J.C., Teresa Paiva, and Rubens Reimão. "Sleep habits, sleepiness and accidents among truck drivers." Arquivos de neuro-psiquiatria63.4 (2005): 925-930..

5. Anderson, J.E., et al. "Obesity is associated with the future risk of heavy truck crashes among newly recruited commercial drivers." Accident Analysis \& Prevention 49 (2012): 378-384..

6. James evan, James evan, J.Goglia, National Trasportation Safty Board, Annual report to congress,1999, 490 L'Enfant Plaza, S.W., NTSB/SPC-00/03 Washington, D.C. 20594.

7. Capodaglio, P., et al. "Functional limitations and occupational issues in obesity: a review." International Journal of Occupational Safety and Ergonomics 16.4 (2010): 507-523..

8. Doyle, K., Drug use high among commercial truck drivers. Oct 25,2013.

9. Anderson, J.E., et al., Obesity is associated with the future risk of heavy truck crashes among newly recruited commercial drivers. Accident Analysis \& Prevention, 2012. 49: p. 378-384.

10. Hosmer Jr, D.W., Stanley Lemeshow, and Rodney X. Sturdivant. Applied logistic regression. Vol. 398. John Wiley \& Sons, 2013.

11. Stutts, J.C., Jean W. Wilkins, and Bradley V. Vaughn. "Why do people have drowsy driving crashes." Input from drivers who just did 202/638 (1999): 5944..

12. Cox, D.R. and E.J. Snell, Analysis of binary data. Vol. 32. 1989: CRC Press.

13. Nagelkerke, Nico JD. "A note on a general definition of the coefficient of determination." Biometrika 78.3 (1991): 691-692.

14. Hosmer Jr, David W., Stanley Lemeshow, and Rodney X. Sturdivant. Applied logistic regression. Vol. 398. John Wiley \& Sons, 1989.

15. Car crashes rank among the leading causes of death in the United States, Traffic Safety Culture Index April, AAA Foundation of Traffic Safety, 2008

16. Cerrelli, Ezio C. Trends in large truck crashes. No. HS-808 690. 1998.

17. Luke, R., and Gert J. Heyns. "Reducing risky driver behaviour through the implementation of a driver risk management system." Journal of Transport and Supply Chain Management 8.1 (2014): 10-pages. 